\title{
1 Recent advances in isotopes as palaeolimnological proxies
}

3 Melanie J. Leng ${ }^{1}$ and Andrew C. G. Henderson ${ }^{2}$

$4{ }^{1}$ Department of Geology, University of Leicester, Leicester, LE1 7RH, UK and NERC Isotope 5 Geosciences Laboratory, British Geological Survey, Nottingham, NG12 5GG, UK; ${ }^{2}$ School of 6 Geography, Politics \& Sociology, Newcastle University, Newcastle upon Tyne, NE1 7RU, $7 \quad$ UK; *Author for correspondence (e-mail: mjl@bgs.ac.uk)

9 Key words: Stable isotopes, Biogenic silica, Compound specific isotope analysis, Clumped 10 isotopes, Chironomids, Palaeolimnology

\section{Abstract}

13 Isotope geochemistry is an essential part of environmental and climate change research and over the last few decades has contributed significantly to our understanding of a huge array of environmental problems, not least in palaeolimnology and limnogeology. Here we describe some of the recent developments in the use of stable isotopes in palaeo-lake research. These are: better preparation, analysis, and interpretation of biogenic silica oxygen and silicon isotopes; extraction and characterisation of specific compounds such as leaf waxes and algal lipids for isotope analysis; determining the excess of ${ }^{13} \mathrm{C}-{ }^{18} \mathrm{O}$ bonds in clumped isotopes; and the measurement of multiple isotope ratios in chironomid chitin. These advances have exciting prospects and it will be interesting to see how these techniques develop further and consequently offer a real advancement in our science over the next decade. 


\section{Introduction}

Isotope geochemistry has become an essential part of environmental and climate change research over the last few decades and has contributed significantly to our understanding of a huge array of environmental problems, which span the whole of Earth system science and not least in palaeolimnology and limnogeology. Continual improvements over time have been made in preparatory methods and mass spectrometry (de Groot 2004), specifically the development of simpler (less time consuming) preparation procedures, decreases in sample size, improved accuracy of measurements and better international standardisation. Now, online systems including continuous flow and laser technology are routine and require very small sample sizes and can measure high numbers of samples often completely automatically. In addition there is an increasing move towards combined measurements of several isotopes in a sample. Here, we describe specific advancements that have, or will, in our opinion, enable significant advancements in palaeolimnology. For example; (1) better preparation, analysis, and interpretation of biogenic silica oxygen and silicon isotopes; (2) extraction and characterisation of specific compounds such as leaf waxes and algal lipids for isotope analysis; (3) determining the excess of ${ }^{13} \mathrm{C}-{ }^{18} \mathrm{O}$ bonds in clumped isotopes; and (4) measurement of multiple isotope ratios in chironomids. We summarise these significant advancements, some of which are relatively new to palaeolimnology so there are few published examples to draw upon. It will be interesting in the next decade to see which of these techniques take off and offer a real advancement in our science.

\section{Biogenic silica oxygen and silicon isotopes}

The use of oxygen and silicon isotopes in biogenic silica was developed by oceanographers in the 1970s and 80's (Labeyrie 1974; Labeyrie and Juillet 1982; Labeyrie et al. 1984) following techniques developed forty to fifty years ago (see Clayton and Mayeda 1963). The oxygen $\left(\delta^{18} \mathrm{O}\right)$, silicon $\left(\delta^{30} \mathrm{Si}\right)$, carbon $\left(\delta^{13} \mathrm{C}\right)$ and nitrogen $\left(\delta^{15} \mathrm{~N}\right)$ compositions of biogenic silica are increasingly being used as proxies for environmental change. $\delta^{18} \mathrm{O}$ tends to be used as a measure of temperature/water composition variation, $\delta^{30} \mathrm{Si}$ for productivity, and $\delta^{13} \mathrm{C}$ and $\delta^{15} \mathrm{~N}$ for nutrient cycling/source investigation. Biogenic silica is a structurally complex mineral especially for $\delta^{18} \mathrm{O}$ measurement; carbon and nitrogen (for $\delta^{13} \mathrm{C}$ and $\delta^{15} \mathrm{~N}$ ) occur in very small quantities in organic material hosted within the structure and can be difficult to extract, while the measurement of $\delta^{30} \mathrm{Si}$ is relatively simple (in comparison to $\delta^{18} \mathrm{O}, \delta^{13} \mathrm{C}$, 
$\left.\delta^{15} \mathrm{~N}\right)$, but there are still uncertainties over the interpretation of the $\delta^{30} \mathrm{Si}$ signal in palaeolimnology, largely as a result of the paucity of studies. However, the recent renewed effort in using biogenic silica in palaeoenvironmental research (especially diatom silica in palaeolimnology; Leng and Barker 2006) has highlighted new ways of dealing with the many issues that accompany its use. Specifically these issues are: contamination; the hydrous layer and associated maturation of diatom silica; controls on the $\delta^{18} \mathrm{O}$; the also the forward potential of $\delta^{30} \mathrm{Si}$ and occluded $\delta^{13} \mathrm{C}$ and $\delta^{15} \mathrm{~N}$ in diatom silica.

\section{Contamination of biogenic silica}

Much effort has been placed on diatom purification and methodological issues prior to isotope analysis (Shemesh et al. 1995; Morley et al. 2004; Lamb et al. 2005; Schleser et al. 2001; Rings et al. 2004; Brewer et al. 2008; Tyler et al. 2007; van Bennekom and van der Gaast 1976; Mackay et al. 2011) as almost pure biogenic silica is required since oxygen and silicon are common elements in other components found in lake sediments (clay, silt, tephra, carbonates) and these can affect the isotope signal or in the case of organic carbon interfere with methodological procedures. While standard chemical leaching and physical separation approaches (sieving, heavy liquids) work well for samples with a high proportion of diatom silica ( $>10 \%)$ more sophisticated and time consuming approaches are required to clean relatively diatom poor $(<10 \%)$ material, where sample sizes are small or where the contaminant is similar in size and density to the diatom silica. Relatively new approaches include SPLITT (gravitational split-flow lateral-transport), micromanipulation, and chemical mass balance modelling. SPLITT is an approach similar to heavy liquid separation (Giddings 1985) whereby individual particles within a sample are separated under laminar flow of water on the basis of their density, size and shape. This approach has been successfully applied to the separation of diatoms from other particles (Schleser et al. 2001; Rings et al. 2004; Leng and Barker 2006). Perhaps most time consuming of all is the use of a micro-manipulation device attached to an inverted microscope with a cellular micro-injector system used to extract individual non diatom particles from a sample. Whilst time consuming, it potentially allows for the final stage removal of particles that are chemically and physically identical to diatoms as well as potentially allowing the separation of diatom species (Snelling et al. in press). Finally, where all other methods fail there is mass balance chemical modelling, whereby a combination of whole-rock geochemistry and electron-optical imaging provides a 
method for the identification, estimation of the amounts and subsequent removal of the effects of different types of contamination (Lamb et al. 2005; Brewer et al. 2008; Mackay et al. 2011; Fig. 1). This approach only works well in samples where the contamination is low relative to the amount of diatom $(<50 \%)$ and the contaminant has a uniform and consistent chemical composition.

The hydrous layer and maturation of oxygen isotopes in biogenic silica

Biogenic silica has an amorphous structure containing Si-O-Si bonds, Si-OH bonds and crystallization water (Knauth and Epstein 1982). These oxygen-bearing compounds (-OH and $\mathrm{H}_{2} \mathrm{O}$ ) can exchange freely with water in their environment, for example with porewater during burial of diatoms (Mopper and Garlick 1971; Kawabe 1978; Mikkelsen et al. 1978; Schmidt et al. 1997; Brandriss et al. 1998; Moschen et al. 2006) or even with water used in the preparation of the material in the laboratory. Because of the ready exchangeability of the hydrous layer, and potentially wide ranging alteration of its isotope composition, it must be removed prior to $\delta^{18} \mathrm{O}$ measurement (Leng and Sloane 2008) making it a complex mineral to analyse. Also the presence of this hydrous layer means that $\delta^{18} \mathrm{O}$ may be influenced by secondary processes that lead to early diagenetic changes. Schmidt et al. (2001) described the influence of silica condensation on the isotopic composition of sedimented opal due to isotope exchange. Moschen et al. (2006) ascribed ${ }^{18} \mathrm{O}$ enrichment of the diatomaceous silica as an effect of biogenic silica maturation (dehydroxylation i.e. reduction of $\mathrm{Si}-\mathrm{OH}$ groups) after removal of the organic coatings. Sedimentary diatomaceous silica is likely to be affected by secondary processes (especially the hydrous parts), however, the predominant portion of the oxygen (c. 90\%) should be bound to silicon in $\mathrm{SiO}_{4}$ tetrahedrons (forming the structurally bound oxygen and this oxygen should be more resistant to alteration). In addition progressive silica maturation does not appear to occur within sedimentary archives because we would expect (but do not see) a trend in $\delta^{18} \mathrm{O}$ leading to a successive isotopic change through time. It might be there is a very slow progression of the maturation process after a fast initial phase of signal alteration and so that some of the $\delta^{18} \mathrm{O}$ signal is in fact acquired soon after the formation of the biogenic silica, during early diagenesis in the water column and during early sediment burial. Dodd and Sharp (2010) showed that maturation is a process that occurs in the water column or at the latest at the sediment-water interface. They comment that in the case of deep lacustrine environments, where the bottom water remains at a nearly constant 
temperature of $4^{\circ} \mathrm{C}$, the re-equilibration of diatom silica with bottom conditions could reduce or remove the conflating effects of temperature on $\delta^{18} \mathrm{O}$ recorded by palaeo-diatom silica and

124 provide direct information on the $\delta^{18} \mathrm{O}$ of the lake water. Overall though lake sediment records are most likely site specific and as our knowledge of the likely effects of maturation increases so does the effort in ensuring analysis is only undertaken of the tetrahedrallybonded oxygen.

The removal of the effect of the exchangeable oxygen contained in hydrous groups is perhaps still the greatest analytical issue and there are two main approaches - chemical removal using a fluorination reagent, and controlled isotopic exchange with subsequent removal by a mass balance calculation. These two analytical protocols are the basis of four methods that have been established to measure $\delta^{18} \mathrm{O}$ in biogenic silica (Chapligin et al. 2011). These methods have been developed relatively independently because there is no commercially available "off the shelf" equipment that allows for dehydration of biogenic silica prior to extraction of the oxygen isotopes and mass spectrometry. A brief summary of the methods is given below:

(1) The Controlled Isotopic Exchange (CIE) method where loosely-bound oxygen is exchanged with oxygen from water vapour (and later mass balanced) before reaction with a material is step heated and reacted with a fluorinating reagent; (3) inductive High-

142 Temperature carbon reduction (iHTR) in which the silica is thermally dehydrated under 143 vacuum; and (4) inert Gas Flow Dehydration (iGFD) during which exchangeable oxygen is 144 thermally removed under a continuous flow of helium.

146 Generally, after the removal or fixing of the exchangeable oxygen by the methods described

147 above, the tetrahedrally-bonded oxygen from the Si-O-Si structure is liberated either by 148 conventional (slow reaction in heated nickel cylinders) or laser (fast reaction by laser heating)

149 fluorination with $\mathrm{ClF}_{3}, \mathrm{BrF}_{5}$ or $\mathrm{F}_{2}$. The oxygen is then measured as $\mathrm{CO}_{2}, \mathrm{CO}$ or $\mathrm{O}_{2}$ by mass 150 spectrometry. Chapligin et al. (2011) undertook an isotope standard comparison study, which 151 shows for the first time that despite procedural and methodological differences across the eight laboratories that participated in the standard comparison study (using the 4 different methods on six working standards), they produced data on working standards that have standard deviations for $\delta^{18} \mathrm{O}$ between 0.3 and $0.9 \%$ o $(1 \sigma)$ and shows that the exchangeable 
oxygen issue, at least analytically, is dealt with relatively consistently.

Oxygen isotopes in diatom silica

To date the most successful studies have been conducted on diatom silica in areas where the $\delta^{18} \mathrm{O}_{\text {diatom }}$ registers changes in the $\delta^{18} \mathrm{O}$ composition of the lake water (rather than temperature) which is then related to other aspects of climate, for example the precipitation/evaporation balance (Rioual et al. 2001), the amount of precipitation in the tropics (Barker et al. 2001), and changes in the source of precipitation in Northern Europe (Shemesh et al. 2001a,b; Rosqvist et al. 2004; Jones et al. 2004). However, diatom oxygen signals do contain a component of temperature, although empirical studies of the $\delta^{18} \mathrm{O}$ of diatom frustules have indicated a discrepancy in the silica-water fractionation factor between modern/cultured diatoms and sediment-derived diatom records (e.g. Schmidt et al. 2001; Moschen et al. 2005; 2006; Tyler et al. 2008). $\delta^{18} \mathrm{O}$ values of modern diatoms collected as living specimens from natural, freshwater environments record a temperature dependent silica-water fractionation nearly identical to that reported by Brandriss et al. (1998) and Moschen at al. (2005) from cultured diatom samples, both indicating a mineral-water temperature coefficient of $-0.2 \% /{ }^{\circ} \mathrm{C}$. However, caution is needed, as described previously, some studies suggest that the signal is incorporated during sinking in the water column and/or in the bottom waters or at the sediment surface under different temperatures. Overall, while $\delta^{18} \mathrm{O}_{\text {diatom }}$ is likely not a good proxy for temperature alone there are many other aspects of climate this it is ideally suited.

\section{Silicon isotopes in diatom silica}

In oceans there have been studies that have confirmed the link between diatom silicon utilization and $\delta^{30} \mathrm{Si}$ compositions (De La Rocha et al. 2000; Varela et al. 2004; Cardinal et al. 2005). Consequently, $\delta^{30} \mathrm{Si}$ data from the sedimentary records have been used as a proxy to reconstruct palaeoproductivity (or more strictly marine silicic acid use by diatoms relative to initial dissolved silicic acid concentrations; i.e. De La Rocha et al. 1998; Brzezinski et al. 2002). In continental waters, there have been relatively fewer $\delta^{30} \mathrm{Si}$ investigations, and those reported tend to be on major rivers (De La Rocha et al. 2000; Ding et al. 2004; 2011). Silicon in rivers comprises both dissolved and particulate matter, and measurement of both allows an 
assessment of weathering as well as productivity-related fractionation. These studies, whilst highlighting the complexity of lake systems (potentially having several weathering component fluxes) show that $\delta^{30} \mathrm{Si}$ values are consistent with Si concentrations (De La Rocha et al. 2000). They also suggest that $\mathrm{Si}$ isotope fractionation is independent of species and (direct) temperature, offering potential information on changes in nutrient supply and limnology. In palaeolimnology, studies have focused on the relationship between climate, diatom productivity, and lake mixing regimes (Alleman et al. 2005) though to date there are rather few studies to draw upon. Given the current interest in $\delta^{30} \mathrm{Si}$ in palaeolimnology, we are likely to see a surge of studies in the years to come especially accompanying the use of $\delta^{18} \mathrm{O}$ in diatom silica (Leng and Barker 2006).

One of the first studies of lacustrine $\delta^{30} \mathrm{Si}$ is from Lake Rutundu, Mt. Kenya, over the last $\sim 38$ ka, which described a small, well studied lake/catchment in order to highlight processes that may have operated at biome to continental scales during the Late Quaternary (Street-Perrott et al. 2008). A combination of lake sediment fluxes and stable isotope $\left(\delta^{13} \mathrm{C}, \delta^{15} \mathrm{~N}, \delta^{18} \mathrm{O}\right.$, $\delta^{30} \mathrm{Si}$ ) data showed that under glacial conditions high diatom productivity was maintained by substantial transport of dissolved $\mathrm{SiO}_{2}$ and soil nutrients from a sparse, leaky, terrestrial ecosystem. During a period of high monsoon rainfall and seasonality rapid Si cycling by fireprone grassland was associated with substantial aeolian transport of opal phytoliths by smoke plumes, but greatly reduced nutrient flux in runoff. Invasion of tall, subalpine shrubs subsequently enhanced landscape stability, leading to very low sediment fluxes of both phytoliths and diatoms. In another study Chen et al. (2012) measured $\delta^{30} \mathrm{Si}$ from diatoms in sediments from Lake Huguangyan, a closed crater lake in China. The results show a

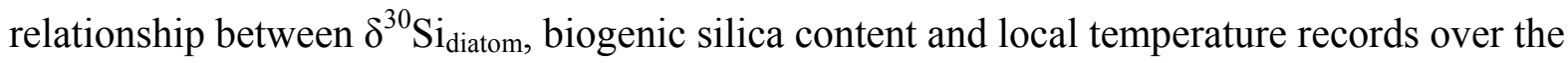
last 50 years and northern hemisphere palaeotemperatures over the last 2000 years. They interpret higher $\delta^{30} \mathrm{Si}_{\text {diatom }}$ as an indication of greater dissolved silicic acid utilization at higher temperature while lower $\delta^{30} \mathrm{Si}_{\text {diatom }}$ reflects decreased utilization at lower temperature.

\section{Carbon and nitrogen isotopes in occluded organic matter in diatom silica}

Increasingly researchers are using isotope methods based on single organisms that use dissolved carbon and nitrogen for photosynthesis to reveal changes in the carbon and nitrogen cycle rather than bulk methods. In this context diatom frustule contains proteins (pleuralins, 
221 silaffins and long chain polyamines) incorporated during growth that are central to silica sequestration and become entombed within the silica cell wall structure (Hecky et al. 1973; Kroger and Poulson 2008; Bridoux et al. 2010). Analyses of $\delta^{13} \mathrm{C}_{\text {diatom }}$ (Jacot Des Combes et al. 2008; Schneider-Mor et al. 2005; Shemesh et al. 1995) and $\delta^{15} \mathrm{~N}_{\text {diatom }}$ (e.g., Crosta and Shemesh 2002; Crosta et al. 2005) in Southern Ocean cores highlight the feasibility and applicability of these techniques in palaeoceanography. Pre-analysis the diatom silica has to be prepared by removing all external mucilage organic matter. Since the amount of occluded organic matter is small within diatom silica, several milligrams of material is used for the analysis. However, these methods are not generally used in palaeolimnology where more complex nutrient cycling can pose significant challenges for the interpretation of the palaeoenvironmental record. There are advantages in using the isotope composition of occluded organic matter within the silica of diatoms. It has been suggested that the isotope composition within the diatom cell walls is not affected by post depositional degradation and therefore potentially preserves an unaltered signal of surface water conditions during diatom growth (Brenner et al. 1999; Ficken et al. 2000) and in addition avoids the generally heterogeneous nature of bulk sedimentary organic matter (Hurrell et al. 2010). There are unresolved analytical issues outstanding especially with $\delta^{15} \mathrm{~N}_{\text {diatom }}$ measurements, in particular the ongoing discussion of issues around the persulfate-denitrifier technique (Leng and Swann 2010). Few studies exist of isotopes in occluded organic matter in diatom silica. In a recent study of a 25,000-year sediment record from Lake Challa, Mt. Kilimanjaro, $\delta^{13} \mathrm{C}_{\text {diatom }}$ was used in comparison with other proxy data to make inferences about the three major phases in the history of the lake (Fig. 2; Barker et al., in press). From 25 ka to 15.8 ka years BP and from $5.5 \mathrm{ka}$ to present, $\delta^{13} \mathrm{C}_{\text {diatom }}, \delta^{13} \mathrm{C}_{\text {bulk }}$ and high diatom content suggests high aquatic and terrestrial productivity. From 15.8 to 5.5 ka the correlation between $\delta^{13} \mathrm{C}_{\text {diatom }}$ and $\delta^{13} \mathrm{C}_{\text {bulk }}$ breaks down, suggesting carbon supply to the lake satisfied or exceeded demand from productivity. The tripartite division of the data interpreted alongside $\delta^{18} \mathrm{O}_{\text {diatom }}$ show that the demand exerted by lake productivity regulated by nutrient availability and changes in carbon supplied from the catchment is forced by climate as indicated hydrological interpretation of $\delta^{18} \mathrm{O}_{\text {diatom }}$ (Fig. 2; Barker et al. in press).

\section{Compound specific isotope analysis}


254 (CSIA) to lacustrine sediments; in particular, the use of $\delta^{13} \mathrm{C}$ to reconstruct changes in vegetation and primary productivity, and $\delta \mathrm{D}$ to track changes in aridity and precipitation. The CSIA approach relies on the extraction and quantification of organic molecules and on the assumption they can be related back to a precursor organism, especially the straight-chain hydrocarbons of $n$-alkanes, $n$-alkanols and $n$-alkanoic acids. The long-chain $\left(\mathrm{C}_{27}-\mathrm{C}_{35}\right) n$ alkanes are a main component of the epicuticular waxes of higher plants (Eglinton and Hamilton 1967). In contrast, aquatic algae are dominated by shorter-chain homologues $\left(\mathrm{C}_{17}-\right.$ $\mathrm{C}_{21} n$-alkanes $)$, while the mid-chain homologues $\left(\mathrm{C}_{23}-\mathrm{C}_{25} n\right.$-alkanes $)$ are a dominant component of submerged aquatic macrophytes (Giger et al. 1980; Cranwell et al. 1987; Ficken et al. 2000). On the whole, these molecules are well preserved in lake sediments and once they have been identified and quantified by GC and GC/MS their isotopic composition can be determined using GC-IRMS. Both terrestrial plant leaf waxes and algal lipids therefore, can provide important insights into past environments.

\section{Carbon isotopes in leaf waxes and algal lipids}

The carbon isotope composition $\left(\delta^{13} \mathrm{C}\right)$ of specific compounds has predominantly been used in two ways. Firstly, the $\delta^{13} \mathrm{C}$ of terrestrial plant leaf waxes (long-chain $n$-alkanes and $n$ acids) have been used to distinguish between vegetation using different photosynthetic pathways such as $\mathrm{C}_{3}$ (Calvin-Benson pathway) and $\mathrm{C}_{4}$ (Hatch-Slack pathway) plants. As $\delta^{13} \mathrm{C}$ of the $n$-alkanes differs depending on the photosynthetic pathway utilised by the plant, their isotopic composition can be used to examine changes in vegetation type. For example, the average $\delta^{13} \mathrm{C}$ for $\mathrm{C}_{29} n$-alkane for $\mathrm{C}_{3}$ plants is $-34.7 \%$, while the $\mathrm{C}_{4}$ plants are ${ }^{13} \mathrm{C}$-enriched with an average $\delta^{13} \mathrm{C}$ for $\mathrm{C}_{29} n$-alkane of $-21.4 \%$ ( $c f$. Castañeda et al. 2009a). As changes in vegetation type are largely related to the prevailing climatic conditions such as temperature, aridity and/or atmospheric carbon dioxide $\left(\mathrm{pCO}_{2}\right)$ concentrations, the $\delta^{13} \mathrm{C}$ of plant waxes can be used to reconstruct qualitative changes in past climate. These $\delta^{13} \mathrm{C}$ data can then be used further by taking a semi-quantitative approach using end member-mixing models to reconstruct the proportion of $\mathrm{C}_{4}$ plants present in past vegetation (and therefore the degree of aridity or $p \mathrm{CO}_{2}$ ) by using the $\delta^{13} \mathrm{C}$ values constrained for $\mathrm{C}_{3}$ and $\mathrm{C}_{4}$ plants (e.g. Huang et al. 2006; Castañeda et al. 2007; Sinninghe Damsté et al. 2011).

The second way lipid biomarker $\delta^{13} \mathrm{C}$ can be used is by examining the $\delta^{13} \mathrm{C}$ of aquatic biomarkers, such as short- and mid-chain $n$-alkanes related to algae and submerged and 
emergent macrophytes respectively, to reconstruct changes in primary productivity and carbon source. Analysis of $\delta^{13} \mathrm{C} n$-alkanes has several advantages over the traditional proxy for past aquatic productivity $-\delta^{13} \mathrm{C}$ of bulk organic matter $\left(\delta^{13} \mathrm{C}_{\mathrm{OM}}\right)-$ as the compound specific approach does not incorporate several sources of carbon (terrestrial, aquatic and bacterial) and other processes such as $\mathrm{pH}$ and dominant inorganic carbon species, which have the potential to influence $\delta^{13} \mathrm{C}_{\mathrm{OM}}$. In fact, it is difficult to deconvolute all of the confounding factors that determine $\delta^{13} \mathrm{C}_{\mathrm{OM}}$ in a lake. For example, ${ }^{13} \mathrm{C}$-enriched values of $\delta^{13} \mathrm{C}_{\mathrm{OM}}$ tend to indicate increased productivity (Hollander and McKenzie 1991; Leng and Marshall 2004), but enriched $\delta^{13} \mathrm{C}_{\mathrm{OM}}$ values can also be caused by $\mathrm{C}_{4}$-dominated terrestrially derived organic matter, as well as the limitation of dissolved $\mathrm{CO}_{2}$ in lakes causing ${ }^{13} \mathrm{C}$-enrichment of $\delta^{13} \mathrm{C}_{\mathrm{OM}}$ as organisms begin to utilise bicarbonate $\left(\mathrm{HCO}_{3}^{-}\right)$as a function of $\mathrm{pH}$ (Meyers 2003; Aichner et al. 2010a). Conversely, the breakdown of organic matter at the water-sediment interface produces ${ }^{13} \mathrm{C}$-deplete $\mathrm{CO}_{2}$ (aq) that can be incorporated into the carbon pool of the lake and the subsequent $\delta^{13} \mathrm{C}_{\mathrm{OM}}$ would be isotopically lighter, even during a time of greater productivity (Hollander and McKenzie 1991). $\delta^{13} \mathrm{C}_{\mathrm{OM}}$ can also be modified by the abundance of aquatic macrophytes, which can be submerged or emergent and this leads to utilisation of $\mathrm{CO}_{2}$ from the atmosphere and inorganic carbon from the water, thus complicating the $\delta^{13} \mathrm{C}_{\mathrm{OM}}$ signal with respect to palaeoproductivity (Aichner et al. 2010a). Furthermore, in lakes that receive a high proportion of terrestrial organic matter, $\delta^{13} \mathrm{C}_{\mathrm{OM}}$ will not reflect aquatic productivity at all, but rather changes within the lakes catchment (e.g., Lake Malawi; Castañeda et al. $2009 \mathrm{~b}$ ). Therefore, examining the $\delta^{13} \mathrm{C}$ of different component $n$-alkanes can elucidate the processes occurring within a lake's carbon cycle.

A recent study by Aichner et al. (2010a) analysed a sediment core from Lake Koucha, eastern Tibetan Plateau, for $\delta^{13} \mathrm{C}$ of total organic carbon $\left(\delta^{13} \mathrm{C}_{\mathrm{TOC}}\right)$, total inorganic carbon $\left(\delta^{13} \mathrm{C}_{\mathrm{TIC}}\right)$ and the $\delta^{13} \mathrm{C}$ of aquatic macrophyte-derived $n$-alkanes $\left(\delta^{13} \mathrm{C}_{n-\mathrm{C} 23}\right)$, to investigate the controls on the lake's carbon cycle over the deglacial and Holocene. The authors found a correlation between TOC, total amount of $n-\mathrm{C} 23$ and $\delta^{13} \mathrm{C}_{\mathrm{TOC}}$ and $\delta^{13} \mathrm{C}_{n-\mathrm{C} 23}$, which indicates Lake Koucha was macrophyte-dominated before 8000 cal. years BP (Fig. 3). Subsequent to this, the lake switched from a saline to freshwater system $\sim 7200$ cal. years BP and the lake began to be colonised with phytoplankton, before being dominated by algae, in particular, diatoms from 6100 cal. years BP (Fig. 3; Aichner et al., 2010a). There is a large range of $\delta^{13} \mathrm{C}_{n-\mathrm{C} 23}$ 
318 values through the record ( $-23.5 \%$ to $-12.6 \%$ ), with lowest values during the greatest

319 macrophyte abundance and the highest during the period of phytoplankton dominance.

320 Therefore, Aichner et al. (2010a) argue $\delta^{13} \mathrm{C}_{n-\mathrm{C} 23}$ is an excellent indicator of carbon-limiting

321 conditions that lead to the assimilation of isotopically ${ }^{13} \mathrm{C}$-enriched carbon species (Fig. 3).

323 The cause of this carbon limitation may be very localised (eg. within a single macrophyte bed) or could be induced by higher primary productivity. A comparison of $\delta^{13} \mathrm{C}_{n-\mathrm{C} 23}$ with $\delta^{13} \mathrm{C}_{\mathrm{TOC}}$ from Lake Koucha (Fig. 3) and the offset between the two $\left(\delta^{13} \mathrm{C}_{n-\mathrm{C} 23}-\delta^{13} \mathrm{C}_{\mathrm{TOC}}\right)$ provides information about the relative contributions of aquatic macrophytes to the overall organic carbon pool. The isotopic signature of bicarbonates assimilated by macrophytes show large variations, as indicated by $\delta^{13} \mathrm{C}_{\mathrm{TOC}}$ (Fig. 3), while the $\delta^{13} \mathrm{C}_{\mathrm{TIC}}$ increases by $8 \%$ o during the phytoplankton maximum (period III, Fig. 2), suggesting the more positive $\delta^{13} \mathrm{C}_{n \text {-C23 values }}$ during this time are caused by enrichment of the inorganic carbon pool (Aichner et al., 2010a). However, as there are multiple sources of inorganic carbon in a lake, $\delta^{13} \mathrm{C}_{\text {TIC }}$ will vary according to the source. Therefore the offset between $\delta^{13} \mathrm{C}_{n-\mathrm{C} 23}$ and $\delta^{13} \mathrm{C}_{\mathrm{TIC}}$ provides a more robust assessment for changes in carbon-limiting conditions within Lake Koucha (Fig. $3)$.

336 The $\delta^{13} \mathrm{C}$ analysis of long-, mid- and short-chain lipid biomarkers deposited in lake sediments

337 has elucidated our understanding of past environmental changes, in particular, changes in

338 terrestrial and aquatic vegetation. As the studies discussed above highlight, the ability to analyse specific compounds for $\delta^{13} \mathrm{C}$ means for the first time we are beginning to understand the different parts of the carbon cycle within lake systems.

\section{Hydrogen isotopes in leaf waxes and algal lipids}

344 The deuterium isotope composition $(\delta \mathrm{D})$ of long-chain leaf waxes and short-chain algal lipids

345 e.g. $n$-alkanes and $n$-alkanoic acids, is increasingly being used as a proxy for past

346 hydrological fluctuations. The $\delta \mathrm{D}$ composition of meteoric water is influenced by a number

347 of environmental factors, such as temperature, source moisture, amount of precipitation, and 348 continental rainout (Bowen and Revenaugh 2003). Therefore, changes in climate that affect 
the isotopic composition of precipitation can be tracked using the $\delta \mathrm{D}$ composition of leaf waxes, as precipitation is the source water for higher plants, while algal lipid $\delta \mathrm{D}$ values register a change in the hydrological balance of the lake as they record surface water $\delta \mathrm{D}$. A number of studies have demonstrated on a continental to global scale that the $\delta \mathrm{D}$ of precipitation controls the $\delta \mathrm{D}$ of plant leaf waxes (e.g., Bi et al. 2005; Sachse et al. 2006; Smith and Freeman 2006; Hou et al. 2008; Rao et al. 2009; Polissar and Freeman 2010), while the $\delta \mathrm{D}$ of lake water is an important control of algal lipid $\delta \mathrm{D}$ (e.g., Sauer et al. 2001; Huang et al. 2004; Sachse et al. 2004). These first-order relationships over a wide spatial scale suggest the $\delta \mathrm{D}$ of various biomarkers can be a powerful palaeohydrological proxy in lake sediments. However, other factors have the potential to alter the $\delta \mathrm{D}$ of leaf wax or algal lipids, such as biosynthetic fractionations, (evapo)transpiration and ecological turnover, and must be considered before full palaeoclimatic inferences can be made.

As in many isotope systems, there is a fractionation between the isotope composition of water and the isotope composition of the biomarker. In the case of leaf waxes and algal lipids a biosynthetic fractionation of $\delta \mathrm{D}$ from prevailing meteoric and lake water has been documented in higher plants (Smith and Freeman 2006; Hou et al. 2008; Feakins and Sessions 2010) and algae (Zhang and Sachs 2007; Zhang et al. 2009). Determining this apparent fractionation between meteoric and/or lake water and lake sediment $\delta \mathrm{D}$ proxies is essential for the interpretation of lake-sediment $\delta \mathrm{D}$ records. Down core variations in $\delta \mathrm{D}$ can be interpreted as fluctuations in hydrology, if we assume biosynthetic fractionation of the same lipid derived from a different species is identical. If not, changes in $\delta \mathrm{D}$ can equally result from shifts in plant or algal species (ecological turnover) and the overall $\delta \mathrm{D}$ trends will therefore be driven by differences in isotopic fractionation. For example, the fractionation between meteoric water and leaf waxes originating from grasses and woody species range $73 \%$ to $-242 \%$ and from $-57 \%$ o to $-220 \%$, respectively (Liu and Yang 2008), although smaller fractionations have been documented in arid and semi-arid environments (up to 90\%; Feakins and Sessions 2010). These fractionations are further complicated depending on the photosynthetic pathway used by the plant $\left(\mathrm{C}_{3}\right.$ vs. $\mathrm{C}_{4}$ vegetation), as studies have shown $n$ alkanes from $\mathrm{C}_{4}$ grasses to have more positive $\delta \mathrm{D}$ values than those from $\mathrm{C}_{3}$ grasses (Smith and Freeman 2006; Liu et al. 2006a; Liu and Yang 2008; McInerney et al. 2011). However, some studies suggest $C_{3}$ plants have increased $\delta \mathrm{D}$ values compared to their $\mathrm{C}_{4}$ counterparts (Chikaraihsi and Narako 2003), while others haven't observed any difference between $C_{3}$ and $\mathrm{C}_{4}$ plants (Bi et al. 2005; Rao et al. 2009). Liu and Yang (2008) suggest the main influence 
on $\delta \mathrm{D}$ is the vegetation-form (i.e. tree, shrub or grass as they utilise very different source waters). A recent study by Rao et al. (2009) however found no apparent relationship between $\delta \mathrm{D}$ and vegetation type (e.g. forest vs. grassland or $\mathrm{C}_{3}$ vs. $\mathrm{C}_{4}$ plants). In an aquatic setting, culture studies have demonstrated that while algal lipid $\delta \mathrm{D}$ reflect the $\delta \mathrm{D}$ of the source water, there were systematic variations in the fractionation between the isotope composition of water and different lipid homologues within a single species (Zhang and Sachs 2007). Perhaps more importantly, Zhang and Sachs (2007) document a $-90 \%$ to $-100 \%$ difference in hydrogen fractionation within a single lipid class across five species of algae. The authors therefore advised caution against the use of lipids that have multiple sources (Zhang and Sachs 2007). Despite this, a number of studies have shown a strong relationship between $\delta D$ of short-chain lipids in surface lake sediments, which are potentially from multiple sources, and lake water $\delta$ D (Huang et al. 2004; Sachse et al. 2004; Shuman et al. 2006; Hou et al. 2008; Henderson et al. 2010a).

The CSIA approach means it is possible to measure the $\delta \mathrm{D}$ composition of multiple compounds within the same stratigraphic layer and as a result some studies have begun to explore the use of long-chain (terrestrially-derived) and short-chain (aquatic-derived) $n$ alkane $\delta \mathrm{D}$ as a proxy for evapotranspiration or water balance in some lakes. For example, a $30 \%$ difference in $\delta \mathrm{D}$ between terrestrially- and aquatic-derived $n$-alkanes was observed across a range of small, groundwater-fed lakes in Europe (Sachse et al. 2004). As the terrestrial $n$-alkanes record meteoric $\delta \mathrm{D}$, but were enriched by $30 \%$ compared to the aquatic $n$-alkane $\delta \mathrm{D}$, the offset between the two (terrestrial $\delta \mathrm{D}$ mean $=-128 \%$; aquatic $\delta \mathrm{D}$ mean $=-$ $157 \%$ ) is thought to derive from evapotranspiration in the terrestrial plant leaf (Sachse et al. 2004). This means there is the potential to reconstruct changing evapotranspiration through time, although this assumes the moisture source for a lake doesn't change. Mügler et al. (2008) found terrestrial $n$-alkanes $\left(C_{29}\right)$ enriched by $\sim 30 \%$ compared to aquatic $n$-alkanes $\left(\mathrm{C}_{23}\right)$ in Lake Holzmaar, a groundwater fed lake in Germany, supporting the analysis by Sachse et al. (2004). However, in the semi-arid and arid setting of the Tibetan Plateau, terrestrial $n$-alkanes were isotopically depleted by $\sim 60 \%$ compared to aquatic $n$-alkanes in two lakes (Nam Co, Jiana Co) (Mügler et al. 2008). The difference in offset between $\mathrm{C}_{29}$ and $\mathrm{C}_{23}$ n-alkanes in Germany compared to Tibet results from the moisture balance of the lakes. The $\delta \mathrm{D}$ of Lake Holzmaar surface water is in isotopic equilibrium with input water (precipitation and groundwater), while Nam Co and Jiana Co are isotopically enriched by $30 \%$ to $50 \%$, suggesting evaporative concentration of lake waters at these two sites. As a 
417 result Mügler et al. (2008) suggest a positive $\Delta \delta D C_{29}-C_{23}$ is a good indicator of humid

418 conditions, while a negative $\Delta \delta \mathrm{D} \mathrm{C}_{29}-\mathrm{C}_{23}$ reflects semi-arid to arid conditions and therefore

$419 \Delta \delta \mathrm{D} \mathrm{C}_{29}-\mathrm{C}_{23}$ can potentially be used as a palaeoaridity indicator and to estimate the

420 evaporation to inflow ratio to reconstruct past water balance.

422 The influence of relative humidity and evaporative enrichment of soil and leaf water on $\delta \mathrm{D}$

423 can complicate the application of the $\Delta \delta \mathrm{D} \mathrm{C}_{29}-\mathrm{C}_{23}$ approach to lake sediments. Aichner et al.

424 (2010b) tested the application of $\Delta \delta \mathrm{D} \mathrm{C}_{29}-\mathrm{C}_{23}$ to Tibetan lakes by examining surface sediment

425 and aquatic macrophytes from a number of sites across the NE Tibetan Plateau. There was no

426 observable offset between the $\delta \mathrm{D}$ of terrestrial and aquatic $n$-alkanes and when applied to a

427 lake sediment record (Lake Koucha), there was also no significant offset in $\delta \mathrm{D}$ between the

$428 n$-alkanes down core (Aichner et al. 2010b). The authors suggest this results from the

429 evapotranspiration of soil and leaf water in tandem with evaporative enrichment of lake water

430 in particularly arid environments and therefore the palaeoardity proxy of $\Delta \delta \mathrm{D} \mathrm{C}_{29}-\mathrm{C}_{23}$ is not

431 uniformly applicable. A number of studies have also assessed the influence of relative

432 humidity and evaporative enrichment of soil and leaf water on $\delta \mathrm{D}$. Hou et al. (2008) found

433 that halving the relative humidity from $80 \%$ to $40 \%$ in a growth chamber study produced

434 only $\sim 7 \%$ enrichment in the $\delta \mathrm{D}$ of leaf wax, which they attribute to soil evaporation.

435 However, McInerney et al. (2011) found no enrichment of $\delta \mathrm{D}$ of leaf waxes in a growth

436 chamber, but documented enrichment in a field study as a result of changes in relative

437 humidity. They suggest this is explained by D-enrichment of the grass source water by

438 evaporation from soils, rather than within leaf evapotranspiration. In juxtaposition to this is a

439 study of an arid ecosystem that suggests leaf transpiration is responsible for the D-enrichment

440 of $\delta \mathrm{D}$ in leaf waxes, rather than soil evaporation as many plant species take up groundwater

441 and precipitation without fractionation (Feakins and Sessions 2010). While a latitudinal study

442 of 28 catchments of varying climate, ecosystem and vegetation types by Polissar and

443 Freeman (2010) highlights net fractionation between the $\delta \mathrm{D}$ of leaf waxes and meteoric $\delta \mathrm{D}$

444 varies according to the ecosystem. Open grasslands were more sensitive to changes in aridity,

445 whereas closed forested ecosystems have reduced soil water loss and therefore less sensitivity

446 to evaporative enrichment (Polissar and Freeman 2010).

448 Despite the complications highlighted above, $\delta \mathrm{D}$ is still a very useful palaeolimnological tool 449 and continues to be successfully applied in a number of regions. However, important 
consideration of the myriad of confounding factors is essential to make climatic interpretations. The $\delta \mathrm{D}$ composition of terrestrial and/or aquatic biomarkers is predominantly used in non-carbonate precipitating lake ecosystems, so it is rare to compare the $\delta \mathrm{D}$ of a leaf wax and the more traditional palaeohydrological indicator of $\delta^{18} \mathrm{O}$ of carbonate. In a recent study, Liu et al. (2008) used a multi-isotope proxy record generated from the same core (QHN3/1) to disentangle the late Holocene climatic impact on Lake Qinghai, a large lake on the NE Tibetan Plateau. They established the $\delta \mathrm{D}$ of fatty acid $\mathrm{C}_{28}\left(\mathrm{C}_{28} \delta \mathrm{D}\right)$ as an indicator of precipitation $\delta \mathrm{D}$ and used the $\delta^{18} \mathrm{O}$ of lake carbonate $\left(\delta^{18} \mathrm{O}_{\text {carb }}\right)$ as a proxy for regional water balance (see fig. 4). The $\delta^{18} \mathrm{O}_{\text {carb }}$ record is in good accordance with other high-resolution late Holocene isotope records from Lake Qinghai (Henderson et al. 2010b). The comparison highlights coherent trends between the two proxies, although the $\mathrm{C}_{28} \delta \mathrm{D}$ lags the $\delta^{18} \mathrm{O}_{\text {carb }}$ record, which might reflect the time taken for the integration of terrestrial leaf waxes from the catchment into the sediment record compared to autochthonous deposition of carbonates. However, the records show coupled reductions in $\mathrm{C}_{28} \delta \mathrm{D}$ and $\delta^{18} \mathrm{O}_{\text {carb }}$ between $\sim 1500$ to 1250 calendar years BP, which is coincident with a regional Little Ice Age (LIA) that has previously been documented in the lake ( $c f$. Henderson et al. 2010b). In addition, a comparison of the $\mathrm{C}_{28} \delta \mathrm{D}$ and $\delta^{18} \mathrm{O}_{\text {carb }}$ records with independent temperature and salinity proxy data based on alkenones from the same QHN3/1 core (Liu et al. 2006) suggest this LIA reduction in $\delta \mathrm{D}$ values resulted from changes in moisture source to the region, rather than an increase in monsoon precipitation. The alkenone data show the LIA to be cold and arid, while the isotope records suggest Lake Qinghai was fresher. As variations in $\mathrm{C}_{28} \delta \mathrm{D}$ and $\delta^{18} \mathrm{O}_{\text {carb }}$ can also be caused by a change in the isotope composition of input water, Liu et al. (2008) suggest there was more westerly-derived moisture, which is isotopically deplete as a result of continental rainout. This interpretation of the isotope data during the LIA is further supported by other high-resolution records from other basins within the Lake Qinghai region (Henderson et al. 2010b), suggesting regionally coherent patterns in climate change during the LIA.

\section{Clumped isotopes in lake carbonates}

Stable isotope geochemistry has been used as an indicator of palaeoclimate since the work of McCrea (1950) and Urey et al. (1951) highlighted the potential for $\delta^{18} \mathrm{O}$ to be used for palaeotemperature reconstruction. The technique has been routinely applied in 
palaeolimnology of all geological ages (Leng and Marshall 2004). In lacustrine environments, stratigraphic changes in $\delta^{18} \mathrm{O}$ values are commonly attributed to changes in temperature, air mass or precipitation/evaporation ratio. However, a perennial problem though in the quantitative interpretation of geochemical proxies for climate is that the systems are essentially underdetermined: in other words the variables that can be measured in the sediments (generally $\delta^{18} \mathrm{O}$ and $\delta^{13} \mathrm{C}$ in carbonates, biogenic silica, organic matter) are influenced by a wide range of interlinked environmental processes rather than a single factor. For example, a change in temperature will produce a shift in the equilibrium $\delta^{18} \mathrm{O}$ of carbonate forming in a lake. However, the same temperature change will affect the $\delta^{18} \mathrm{O}$ of the rainfall and may also affect rates of evaporation, both in the lake and in the catchment. All these factors will influence the $\delta^{18} \mathrm{O}$ of the lacustrine components so a single variable cannot be ascribed. In general, therefore, it is impossible to measure the $\delta^{18} \mathrm{O}$ of carbonates and silicates and translate the values into absolute or even relative temperature variation without making some very significant assumptions (Leng and Marshall 2004). Thus, this conventional approach amounts to solving several unknowns (most specifically temperature and $\delta^{18} \mathrm{O}$ of water) with a single constraint (i.e., $\delta^{18} \mathrm{O}$ of carbonate)

498 Carbonate clumped-isotope thermometry has the potential to directly constrain both temperature and $\delta^{18} \mathrm{O}$ of carbonate independently. Carbonate clumped-isotope thermometry constrains carbonate precipitation temperatures based on the temperature-dependent 'clumping' of ${ }^{13} \mathrm{C}$ and ${ }^{18} \mathrm{O}$ into bonds with each other in the solid carbonate phase alone, independent of the ${ }^{18} \mathrm{O}$ of the waters from which the mineral grew (e.g., Schauble et al. 2006; Eiler 2007). The ${ }^{13} \mathrm{C}-{ }^{18} \mathrm{O}$ bond enrichment relative to the 'stochastic', or random, distribution of all $\mathrm{C}$ and $\mathrm{O}$ isotopes among all possible isotopologues is determined by digesting pure carbonates and measuring the $\delta^{18} \mathrm{O}, \delta^{13} \mathrm{C}$, and abundance of mass-47 isotopologues (mostly ${ }^{13} \mathrm{C}^{18} \mathrm{O}^{16} \mathrm{O}$ ) in product $\mathrm{CO}_{2}$. The latter, termed the $\Delta_{47}$ value, varies with carbonate growth temperature (Ghosh et al. 2006a). Few applications have been made (or at least published) within palaeolimnology to date, but one study calculated the timing of the Colorado Plateau uplift by estimating depositional temperatures of Tertiary lake sediments that blanket the

510 plateau interior and adjacent lowlands using the carbonate clumped-isotope

511 palaeothermometer (Huntington et al. 2010). Comparison of modern and ancient samples

512 deposited near sea level provided an opportunity to quantify the influence of climate, and therefore assess the contribution of changes in elevation to the variations of surface 
temperature on the plateau. Analysis of modern lake calcite from 350-3300 m elevation revealed a lake water carbonate temperature (LCT) lapse rate of $4.2 \pm 0.6^{\circ} \mathrm{C} / \mathrm{km}$, while analysis of Miocene deposits from lower elevation suggests that ancient LCT lapse rate was

$5174.1 \pm 0.7^{\circ} \mathrm{C} / \mathrm{km}$, and temperatures were $7.7 \pm 2.0^{\circ} \mathrm{C}$ warmer at any elevation in comparison to 518 temperatures predicted by the modern trend. The inferred modern cooling is consistent with

519 other Pliocene temperature estimates, and the consistency of lapse rates through time supports the interpretation that there has been little or no elevation change (Huntington et al.

$5212010)$.

\section{Multiple isotopes in chironomid head capsules}

523 The stable isotope composition of chironomid head capsules is being increasingly used in 524 palaeoenvironmental studies. Recent advances in chironomid isotope research means that multiple isotope ratios $\left(\delta^{13} \mathrm{C}, \delta^{15} \mathrm{~N}, \delta^{18} \mathrm{O}, \delta \mathrm{D}\right)$ can be measured from the same aliquot (Fig. 5).

526 The advantage of the use of chironomids is that in Northern Europe in particular, carbonate lakes tend to be rare, especially those that are not evaporative, and for this reason chironomids (along with diatom silica and aquatic cellulose) are used. Chironomids have the slight advantage over diatom silica in that the individuals tend to be big enough to hand pick (so easier to clean), and unlike aquatic cellulose can be identified under microscopy. $\delta^{18} \mathrm{O}$ and $\delta \mathrm{D}$ of the chironomids have been used as a proxy for the $\delta^{18} \mathrm{O}$ and $\delta \mathrm{D}$ of the water in which they lived, from which there is the potential to reconstruct $\delta^{18} \mathrm{O}$ precipitation (air temperature/source region) in certain types of lakes (Wooller et al. 2004; Wang et al. 2009; Verbruggen et al. 2010). In the latter study the authors explored whether $\delta^{18} \mathrm{O}$ of chironomid capsules can be compared to $\delta^{18} \mathrm{O}$ of bulk carbonates from Lateglacial and early Holocene sediments from Rotsee (Switzerland). Chironomid $\delta^{18} \mathrm{O}$ indicated depleted lake water $\delta^{18} \mathrm{O}$ during the Oldest Dryas period, the Aegelsee and Gerzensee Oscillations, and the Younger Dryas, whereas ${ }^{18} \mathrm{O}$-enriched $\delta^{18} \mathrm{O}$ values were associated with sediments deposited during the Lateglacial interstadial and the early Holocene. Differences in the amplitude of variations in bulk carbonate $\delta^{18} \mathrm{O}$ and chironomid $\delta^{18} \mathrm{O}$ were attributed to differential temperature effects on oxygen isotope fractionation during the formation of carbonates and chironomid head capsules or seasonal changes of lake water $\delta^{18} \mathrm{O}$, potentially affecting $\delta^{18} \mathrm{O}$ to different extents. $\delta^{13} \mathrm{C}, \delta^{15} \mathrm{~N}$ and $\delta \mathrm{D}$ in chironomids are thought to reflect the isotopic composition of

544 the invertebrate food, modified by trophic level, and can thus be used as a proxy for feeding ecology (Wooller et al. 2008; van Hardenbroek et al. 2010). In lakes in particular, chironomid 
$546 \quad \delta^{13} \mathrm{C}$ is dependent on whether the larvae fed predominantly on organic matter generated in the

547 photic zone or whether the larvae incorporate methanotropic microorganisms (Jones et al.

548 2008) due to living and burrowing into the sediment (Heiri et al. 2009). One of the potential

549 down sides identified by Heiri et al. (2009) is the possibility for alteration to the chemical

550 composition of the chitin by degradational or diagenetic processes as well as a need to

551 investigate further the chironomid-water/food fractionation processes.

\section{Summary}

553

554 Isotope geochemistry has become more routine within palaeolimnology over the last few

555 decades and it has been employed to address a diverse array of environmental issues ranging

556 from reconstructing past climate to understanding the dynamics of food webs through time.

557 Despite being established as an excellent palaeolimnological tool, continual improvements

558 have occurred in the understanding of the controls on isotope ratios, sample preparation and

559 refining of mass spectrometry techniques. But, perhaps the most important development has

560 been the move away from workhorse 'bulk' isotope methods based on carbonates and organic

561 matter, to the establishment of new proxies from lake sediments, such as, the multiple

562 isotopes that can be extracted from biogenic silica and chironomid chitin, the carbon and

563 hydrogen isotope analysis of specific compounds and the first steps in developing the

564 application of carbonate isotologues in lakes. These have opened up numerous possibilities

565 for the application of stable isotopes to new lakes. It is clear that over the last decade we have

566 taken huge steps in understanding isotope systems, but there still remain a number of

567 questions, especially for their application within palaeolimnology, as each lake is unique and

568 comes with it's own set of specific circumstances. It will be exciting to see how the field

569 develops over the next decade as these techniques are more widely applied to lake sediment 570 records.

\section{Acknowledgements}

574 We thank Phil Barker, Anson Mackay, Steffen Mischke, Zhonghui Liu and Mat Wooller for

575 kindly providing raw data from their studies in order to draw our figures. The authors would

576 like to acknowledge their collaborators and friends who have over the years been a continual

577 source of inspiration for using isotopes in palaeolimnology. In particular, Professor Rick

578 Battarbee has offered incredible support and enthusiasm, especially on the use and 
579 advancement of isotopes in diatom silica in the early years of MJL's research and also the 580 support and encouragement to ACGH for using isotopes on Lake Qinghai during his doctoral 581 research. Many PhD students have over the years worked across UCL and NIGL on isotopes 582 in palaeolimnology, in part driven by Rick's enthusiasm for combining palaeolimnology and 583 isotope geochemistry. We, along with many of our collaborators owe a debt of gratitude to 584 Rick for his unwavering support.

585 
589 Aichner U, Herzschuh H, Wilkes S, Mischke C, Zhang (2010a) Biomarker and compound 590 specific carbon isotope evidence for changing environmental and carbon-limiting conditions 591 at Koucha Lake, Eastern Tibetan Plateau. Journal of Paleolimnology 44: 873-899

592 Aichner U, Herzschuh H, Wilkes A, Vieth J, Böhner (2010b) $\delta$ D values of n-alkanes in 593 Tibetan lake sediments and aquatic macrophytes - a surface sediment study and application to a 16 ka record from Lake Koucha. Organic Geochemistry 41: 779-790

Alleman LY, Cardina D, Cocquyt C, Plisnier P-D, Descy J-P, Kimirei I, Sinyinza D, André L (2005) Silicon isotopic fractionation in Lake Tanganyika and its main tributaries. J Gt Lakes

597 Res 31: 509-519

598 Barker PA, Hurrell ER, Leng MJ, Plessen B, Wolff C, Conley DJ, Keppens E, Milne I, 599 Cumming BF, Laird K, Kendrick CP, Wynn PM, Verschuren D (in press) Carbon cycling 600 within an East African lake from carbon isotope composition of diatom silica: a 25 ka record 601 from Lake Challa, Mt. Kilimanjaro. Quaternary Science Reviews

602 Barker PA, Street-Perrott FA, Leng MJ, Greenwood PB, Swain DL, Perrott RA, Telford J, 603 Ficken KJ (2001) A 14 ka oxygen isotope record from diatom silica in two alpine tarns on 604 Mt. Kenya. Science 292: 2307-2310

605 Bi X, Sheng G, Liu, X, Li C, Fu J (2005) Molecular and carbon and hydrogen isotopic 606 composition of n-alkanes in plant leaf waxes. Org Geochem 36, 1405-1417

607 Bond G, Kromer B, Beer J, Muscheler R, Evans MN, Showers W, Hoffmann S, Lotti-Bond 608 R, Hajdas I, Bonani G (2001) Persistent solar influence on North Atlantic climate during the 609 Holocene. Science 294: 2130-2136

610 Bowen GJ, Revenaugh J (2003) Interpolating the isotopic composition of modern meteoric 611 precipitation. Water Resour Res 39(10), 1299, doi:10.129/2003WR002086

612 Brenner M, Whitmore TJ, Curtis JH, Hodell DA, Schelske CL (1999) Stable isotope (delta C61313 and delta N-15) signatures of sedimented organic matter as indicators of historic lake 614 trophic state. J Paleolimnol 22:205-221

615 Brewer TS, Leng MJ, Mackay AW, Lamb AL, Tyler JJ, Marsh NG (2008) Unravelling 616 contamination signals in biogenic silica oxygen isotope composition: the role of major and 617 trace element geochemistry. J Quaternary Sci 23: 321-330

618 Brandriss ME, O'Neil JR, Edlund MB, Stoermer EF (1998) Oxygen isotope fractionation 619 between diatomaceous silica and water. Geochim Cosmochim Acta 62: 1119-1125

620 Brzezinski MA, Pride CJ, Franck VM, Sigman DM, Sarmiento JL, Matsumoto K, Gruber N, 621 Rau GH, Coale KH (2002) A switch from Si(OH)4 to NO3- depletion in the glacial Southern 622 Ocean. Geophys Res Lett doi:10.1029/12001GL014349

623 Bridoux MC, Ingalls AE (2010) Structural identification of long chain polyamines associated 624 with diatom biosilica in a Southern Ocean sediment core. Geochim Cosmochim Acta 74: 
626 Castañeda IS, Werne JP, Johnson TC (2007) Wet and arid phases in the southeast African tropics since the Last Glacial Maximum. Geology 35: 823-826

628 Castañeda IS, Mulitza S, Schefuß E, Lopes dos Santons RA, Sinnighe Damsté JS, Schouten S 629 (2009a) Wet phases in the Sahara/Sahel region and human migration patterns in North Africa. 630 Proceedings of the National Academy of Sciences of the United States of America: 106:

$631 \quad 20159-20163$

632 Castañeda IS, Werne JP, Johnson TC (2009b) Influence of climate change on algal 633 community structure and primary productivity of Lake Malawi (East Africa) form the Last 634 Glacial Maximum to present. Limnology and Oceanography 54: 2431-2447

635 Cardinal D, Alleman LY, Dehairs F, Savoye N, Trull TW, André L (2005) Relevance of 636 silicon isotopes to Si-nutrient utilization and Si-source assessment in Antarctic waters. Glob 637 Biogeochem Cycles doi:10.1029/2004GB002364

638 Chikaraishi Y, Naraoka H (2003) Compound-specific $\delta \mathrm{D}-\delta^{13} \mathrm{C}$ analyses of n-alkanes 639 extracted from terrestrial and aquatic plants. Phytochemistry 63: 361-371

640 Chen L, Tien-Shun Lin A, Da X, Yi H, Loung-Yie Tsai L, Xu G (2012) Sea-level changes 641 recorded by Cerium anomalies in the Late Jurassic (Tithonian) black rock series of Qiangtang 642 Basin, North-Central Tibet // Oil shale. 18-35. doi: 10.3176/oil.2012.1.03

643 Chapligin B, Leng MJ, Webb EA, Alexandre A, Dodd JP, Ijiri A, Lücke A, Shemesh A, 644 Abelmann A, Herzschuh U, Longstaffe FJ, Meyer H, Moschen R, Okazaki Y, Rees NH, 645 Sharp ZD, Sloane HJ, Sonzogni C, Swann GEA, Sylvestre F, Tyler JJ, Yam R (2011) Inter646 laboratory comparison of oxygen isotope compositions from biogenic silica. Geochim 647 Cosmochim Acta 75: 7242-7256

648 Clayton RN, Mayeda TK (1963) The use of bromine pentafluoride in the extraction of 649 oxygen from oxide and silicates for isotopic analysis. Geochim Cosmochim Acta 27: 43-52

650 Cranwell PA, Eglinton G, Robinson N (1987) Lipids of aquatic organisms as potential 651 contributors to lacustrine sediments-II. Org Geochem 11: 513-527

652 Crosta X, Shemesh A (2002) Reconciling down core anticorrelation of diatom carbon and 653 nitrogen isotopic ratios from the Southern Ocean. Paleoceanogr 17: 1010. doi:

$65410.1029 / 2000$ PA000565

655 Crosta X, Shemesh A, Etourneau J, Yam R, Billy I, Pichon JJ (2005) Nutrient cycling in the 656 Indian sector of the Southern Ocean over the last 50,000 years. Glob Biogeochem Cycles 19: 657 GB3007, doi: 10.1029/2004GB002344

658 De La Rocha CL, Brzezinski MA, DeNiro MJ (2000) A first look at the distribution of the 659 stable isotopes of silicon in natural waters. Geochim Cosmochim Acta 64: 2467-2477

660 De La Rocha CL, Brzezinski MA, DeNiro MJ, Shemesh A (1998) Silicon-isotope 661 composition of diatoms as an indicator of past oceanic change. Nature 395: 680-683

662 De Groot PA (2004). Handbook of Stable Isotope Analytical Techniques. Elsevier, 663 Amsterdam. Pp 1234. 
664

665

666

667

668

669

670

671

672

673

674

675

676

677

678

679

680

681

682

683

684

685

686

687

688

689

690

691

692

693

694

695

696

697

698

699

700

Ding TP, Gao JF, Tian SH, Wang HB, Li M (2011) Silicon isotopic composition of dissolved silicon and suspended particulate matter in the Yellow River, China, with implications for the global silicon cycle. Geochim Cosmochim Acta 75: 6672-6689

Ding T, Wan D, Wang C, Zhang F (2004) Silicon isotope compositions of dissolved silicon and suspended matter in the Yangtze River, China. Geochim Cosmochim Acta 68: 205-216

Dodd JP, Sharp ZD (2010) A laser fluorination method for oxygen isotope analysis of biogenic silica and a new oxygen isotope calibration of modern diatoms in freshwater environments. Geochim Cosmochim Acta 74 (4): 1381-1390

Eglinton G, Hamilton RJ (1967) Leaf epicuticular waxes. Science 156: 1322-1335

Eiler J M (2007) “Clumped-isotope” geochemistry - the study of naturally occurring multiply substituted isotopologues. Earth Planet Sci Lett 262: 309-327.

Feakins SJ, Sessions AL (2010) Controls on the D/H ratios of plant leaf waxes in an arid ecosystem. Geochim Cosmochim Acta 74 (7): 2128-2141

Ficken KJ, Li B, Swain DL, Eglinton G (2000) An n-alkane proxy for the sedimentary inputs of submerged/floating freshwater aquatic macrophytes. Org Geochem 31(7-8): 745-749

Giddings JC (1985) A system based on split flow lateral transport thin (SPLITT) separation cells for rapid and continuous particle fractionation. Sep Sci Technol 20: 749-768

Giger W, Schaffner C, Wakeham SG (1980) Aliphatic and olefinic hydrocarbons in recent sediments of Greifensee, Switzerland. Geochim Cosmochim Acta 44: 119-129

Ghosh P, Adkins J, Affek H, Balta B, Guo W, Schauble E, Schrag D, Eiler J (2006) ${ }^{13} \mathrm{C}-{ }^{18} \mathrm{O}$ bonds in carbonate minerals: a new kind of paleothermometer. Geochim Cosmochim Acta 70: $1439-1456$

Hecky RE, Mopper K, Kilham P, Degens ET (1973) The amino acid and sugar composition of diatom cell walls. Mar Biol 19: 323

Heiri O, Wooller MJ, van Hardenbroek M, Wang YV (2009) Stable isotopes in chitinous fossils of aquatic invertebrates. Pages news 17: 100-102

Henderson AK, Nelson DM, Hu FS, Huang YS, Shuman BN, Williams, JW (2010a)

Holocene precipitation seasonality captured by a dual hydrogen and oxygen isotope approach at Steel Lake, Minnesota. Earth and Planetary Science Letters 300: 205-214

Henderson ACG, Holmes JA, Leng MJ (2010b) Late Holocene isotope hydrology of Lake Qinghai, NE Tibetan Plateau: effective moisture variability and atmospheric circulation changes. Quaternary Sci Rev 29: 2215-2223

Hollander DJ, McKenzie JA (1991) $\mathrm{CO}_{2}$ control on carbon isotope fractionation during aquatic photosynthesis: a paleo-pCO $\mathrm{CO}_{2}$ barometer. Geology 19: 929-932

Hou J, D'Andrea WJ, Huang Y (2008) Can sedimentary leaf waxes record D/H ratios of continental precipitation? Field, model, and experimental assessments. Geochim Cosmichim Acta 72: $3503-3517$ 
Huang Y, Shuman B, Wang Y, Webb III T, Grimm E C, Jacobson Jr G L (2006) Climatic and environmental controls on the variation of $\mathrm{C} 3$ and $\mathrm{C} 4$ plant abundances in central Florida for the past 62,000 years. Palaeogeogr Paleoclimatol Palaeoecol 237: 428-435

Huang Y, Shuman B, Wang Y, Webb III T (2004) Hydrogen isotope ratios of individual lipids in lake sediments as novel tracers of climatic and environmental change: a surface sediment test. J Paleolimnol 31: 363-375

Huntington KW, Wernicke BP, Eiler JM (2010) Influence of climate change and uplift on Colorado Plateau paleotemperatures from carbonate clumped isotope thermometry. Tectonics, 29 Article Number: TC3005, doi:10.1029/2009TC002449.

Hurrell ER, Barker PA, Leng MJ, Vane CH, Wynn P, Kendrick CP, Verschuren D, StreetPerrott FA (2011) Developing a methodology for carbon isotope analysis of lacustrine diatoms. Rapid Communications in Mass Spectrometry 25: 1567-1574

Jacot Des Combes H, Esper O, De la Rocha CL, Abelmann A, Gersonde R, Yam R, Shemesh A (2008) Diatom $\delta^{13} \mathrm{C}, \delta^{15} \mathrm{~N}$, and $\mathrm{C} / \mathrm{N}$ since the Last Glacial Maximum in the Southern Ocean: potential impact of species composition. Paleoceanography, 23, PA4209, 12 PP., 2008 doi: $10.1029 / 2008$ PA001589

Jones RI, Carter CE, Kelly A, Ward S, Kelly DJ, Grey J (2008) Widespread contribution of methane-cycle bacteria to the diets of lake profundal chironomid larvae. Ecology 89: 857-864

Jones VJ, Leng MJ, Solovieva N, Sloane HJ, Tarasov P (2004) Holocene climate of the Kola Peninsula; evidence from the oxygen isotope record of diatom silica. Quaternary Science Reviews 23: 833-839

Kawabe I (1978) Calculation of oxygen isotope fractionation in quartz-water system with special reference to the low temperature fractionation. Geochim Cosmochim Acta 42: 613621

Knauth LP, Epstein S (1982) The nature of water in hydrous silica. Amer. Mineral. 67: 510520

Kroger N, Poulsen N (2008) Diatoms-from cell wall biogenesis to nanotechnology. Annu Rev Genet 42: 83-107

Labeyrie LD (1974) New approach to surface seawater palaeotemperatures using ${ }^{18} \mathrm{O} /{ }^{16} \mathrm{O}$ ratios in silica of diatom frustules. Nature 248: 40-42

Labeyrie LD, Juillet A (1982) Oxygen isotopic exchangeability of diatom valve silica; interpretation and consequences for paleoclimatic studies. Geochim Cosmochim Acta 46: 967-975

Labeyrie LD, Juillet A, Duplessy JC (1984) Oxygen isotope stratigraphy: fossil diatoms vs foraminifera. In: Mann DG. (Ed.) Proceedings of the 7th International Symposium on Recent and Fossil Diatoms. Koeltz, Philadelphia, pp 477-491

Lamb AL, Leng MJ, Sloane HJ, Telford RJ (2005) A comparison of d180 data from calcite and diatom silica from early Holocene in a small crater lake in the tropics. Palaeogeogr Palaeoclimatol Palaeoecol 223: 290-30 
Leng MJ, Barker PA (2006) A review of the oxygen isotope composition of lacustrine diatom silica for palaeoclimate reconstruction. Earth-Sci Rev 75: 5-27

Leng MJ, Marshall JD (2004) Palaeoclimate interpretation of stable isotope data from lake sediments. Quaternary Sci Rev 23: 811-831

Leng MJ, Sloane HJ (2008) Combined oxygen and silicon isotope analysis of biogenic silica. J Quaternary Sci 23: 313-319

Leng MJ, Swann GEA (2010) Stable Isotopes in Diatom Silica. In: Smol JP and Stoermer EF (Eds). The Diatoms: applications for the Environmental and Earth Sciences, Cambridge Press, Pp 667

Liu WG, Yang H (2008) Multiple controls for the variability of hydrogen isotopic compositions in higher plant n-alkanes from modern ecosystems. Glob Change Biol 14: 2166-2177

Liu ZH, Henderson ACG, Huang YS (2008) Regional moisture source changes inferred from late Holocene stable isotope records. Advances in Atmospheric Sciences 25: 1021-1028.

Liu WG, Yang H, Li LW (2006) Hydrogen isotopic compositions of n-alkanes from terrestrial plants correlate with their ecological life forms. Oecologia 150: 330-338

Mackay AW, Swann GEA, Brewer TS, Leng MJ, Morley DW, Piotrowska N, Rioual P, White D (2011) A reassessment of late glacial - Holocene diatom oxygen isotope record from Lake Baikal using a geochemical mass-balance approach. J Quaternary Sci 26: 627-634

McCrea JM (1950) On the isotopic chemistry of carbonates and a paleotemperature scale. J Chem Phys 18: 849-857

McInerney FA, Helliker BR, Freeman KH (2011) Hydrogen isotope ratios of leaf wax nalkanes in grasses are insensitive to transpiration. Geochim Cosmochim Acta 75: 541-554

Meyers PA (2003) Applications of organic geochemistry to paleolimnological reconstructions. Org Geochem 34: 261-289

Mikkelsen SD, De Datta SK, Obcemea WN (1978) Ammonia volatilization losses from flooded rice soils. Soil Sci Soc Am J 42:725-730

Mischke S, Kramer M, Zhang C, Shang H, Herzschuh U, Erzinger J (2008) Reduced early Holocene moisture availability in the Bayan Har Mountains, northeastern Tibetan Plateau, inferred from a multi-proxy lake record. Palaeogeogr Palaeoclimatol Palaeoecol 267: 59-76 Mopper K, Garlick GD (1971) Oxygen isotope fractionation between biogenic silica and ocean water. Geochim Cosmochim Acta 35: 1185- 1187

Morley DW, Leng MJ, Mackay AW, Sloane HJ, Rioual P, Batterbee RW (2004) Cleaning of lake sediment samples for diatom oxygen isotope analysis. J Palaeolimnol 31: 391-401

Moschen R, Lücke A, Parplies J, Radtke U, Schleser GH (2006) Transfer and early diagenesis of biogenic silica oxygen isotope signals during settling and sedimentation of diatoms in a temperate freshwater lake (Lake Holzmaar, Germany). Geochim Cosmochim Acta 70: 4367- 4379 
Moschen R, Lücke A, Schleser GH (2005) Sensitivity of biogenic silica oxygen isotopes to changes in surface water temperature and palaeoclimatology. Geophys Res Let 32 doi:10.1029/2004GL022167

Mügler I, Sachse D, Werner M, Xu BQ, Wu GJ, Yao TD, Gleixner G (2008) Effect of lake evaporation on $\delta \mathrm{D}$ values of lacustrine n-alkanes: a comparison of Nam Co (Tibetan Plateau) and Holzmaar (Germany). Org Geochem 39: 711-729

Polissar PJ, Freeman KH (2010) Effects of aridity and vegetation on plant-wax $\delta \mathrm{D}$ in modern lake sediments. Geochim Cosmochim Acta 74: 5785-5797 doi:10.1016/j.gca.2010.06.018

RaoW, Chen J, Yang J, Ji J, Zhang G (2009) Sr isotopic and elemental characteristics of calcites in the Chinese deserts: Implications for eolian Sr transport and seawater Sr evolution. Geochimic Cosmochim Acta 73: 5600-5618

Rings A, Lücke A, Schleser GH (2004) A new method for the quantitative separation of diatom frustules from lake sediments. Limnol Oceanogr: Methods 2: 25-34

Rioual P., Andrieu-Ponel V, Rietti-Shati M, Battarbee RW, de Beaulieu L-J, Cheddadi R, Reille M, Svobodova H, Shemesh A (2001)High-resolution record of climate stability in France during the Last Interglacial period. Nature 413: 293-296.

Rosqvist GC, Jonsson C, Yam R, Karlen W, Shemesh A (2004) Diatom oxygen isotopes in pro-glacial lake sediments from northern Sweden: a 5000 year record of atmospheric circulation. Quaternary Sci Rev 23: 851-859

Sachse D, Radke J, Gleixner G (2004) Hydrogen isotope ratios of recent lacustrine sedimetary n-alkanes record modern climate variability. Geochim Cosmochim Acta 68: $4877-4889$

Sachse D, Radke J, Gleixner G (2006) $\delta$ D values of individual n-alkanes from terrestrial plants along a climatic gradient - implications for the sedimentary biomarker record. Org Geochem 37: 469-483

Sauer P E, Eglinton TI, Hayes JM, Schimmelmann A, Sessions AL (2001) Compoundspecific $\mathrm{D} / \mathrm{H}$ ratios of lipid biomarkers from sediments as a proxy for environmental and climatic conditions. Geochim Cosmochim Acta 65: 213-222

Schleser GH, Lücke A, Moschen R, Rings A (2001) Separation of diatoms from sediment and oxygen isotope extraction from their siliceous valves - a new approach. Terra Nostra, 2001/3. Schriften der Alfred-Wegener-Stiftung (6th Workshop of the European Lake Drilling Programme, Potsdam.) pp 187-191

Schmidt M, Botz R, Stoffers P, Anders T, Bohrmann G (1997) Oxygen isotopes in marine diatoms: a comparative study of analytical techniques and new results on the isotope composition of recent marine diatoms. Geochim Cosmochim Acta 61: 2275-2280

Schmidt M, Botz R, Rickert D, Bohrmann G, Hall SR, Mann S (2001) Oxygen isotopes of marine diatoms and relations to opal-A maturation. Geochim Cosmochim Acta 65: 201-211

Schauble EA, Ghosh P, Eiler JM (2006) Preferential formation of ${ }^{13} \mathrm{C}-{ }^{18} \mathrm{O}$ bonds in carbonate minerals, estimated using first principles lattice dynamics, Geochim Cosmochim Acta 70: 2510-2529 doi:10.1016/j.gca.2006.02.011 
819 Schneider-Mor A, Yam R, Bianchi C, Kunz-Pirrung M, Gersonde R, Shemesh A (2005)

820 Diatom stable isotopes, sea ice presence and surface temperature records of the past $640 \mathrm{ka}$ in the Atlantic sector of the Southern Ocean. Geophys Res Lett 32 L10704/ 1-4 doi:10.1029/2005GL022543, hdl:10013/epic.22453

823 Shemesh A, Burckle LH, Hays JD (1995) Late Pleistocene oxygen isotope records of biogenic silica from the Atlantic sector of the Southern Ocean. Paleoceanography 10: 179196

Shemesh A, Rietti-Shati M, Rioual P, Battarbee RW, de Beaulieu J-L, Reille M, Andrieu V, Svobodova H (2001a) An oxygen isotope record of lacustrine opal from a European Maar indicates climatic stability during the last interglacial. Geophys Res Lett 28: 2305-2308

829 Shemesh A, Rosqvist G, Rietti-Shati M, Rubensdotter L, Bigler C, Yam R, Karlen W (2001b) Holocene climatic change in Swedish Lapland inferred from an oxygen-isotope record of lacustrine biogenic silica. Holocene 11: 447-454

832 Shuman B, Huang Y, Newby P, Wang Y (2006) Compound specific isotopic analyses track changes in the seasonality of precipitation in the northeastern United States at ca. $8200 \mathrm{cal} \mathrm{yr}$ BP. Quaternary Sci Rev 25: 2992-3002

Sinninghe Damsté JS, Verschuren D, Ossebaar J, Blokker J, van Houten R, van der Meer MTJ, Plessen B, Schouten S (2011) A 25,000-year record of climate-induced changes in lowland vegetation of eastern equatorial Africa revealed by the stable carbon-isotopic composition of fossil plant leaf waxes. Earth Planet Sc Lett 302: 236-246

839 Smith FA, Freeman KH (2006) Influence of physiology and climate on $\delta D$ of leaf wax n-

840 alkanes from C3 and C4 grasses. Geochim Cosmochim Acta 70: 1172-1187

841 Snelling A, Swann, GEA, Leng, MJ, Pike J (in press) A micro-manipulation technique for the 842 purification of diatoms for isotope and geochemical analysis. Silicon

843 Street-Perrott FA, Barker PA, Leng MJ, Sloane HJ, Wooller MJ, Ficken KJ, Swain DL (2008) Towards an understanding of late Quaternary variations in the continental biogeochemical cycle of silicon: multi-isotope and sediment-flux data for Lake Rutundu, Mt Kenya, East Africa, since 38 ka BP. J. Quaternary Sci 23: 375-387

847 Tyler JJ, Leng MJ, Sloane HJ (2007) The effects of organic removal treatment on the 848 integrity of $\delta^{18} \mathrm{O}$ measurements from biogenic silica. J Paleolimnol 37: 491-497

849 Tyler JJ, Leng MJ, Sloane HJ, Sachse D, Glelxner G (2008) Oxygen isotope ratios of 850 sedimentary biogenic silica reflect the European transcontinental climate gradient. J 851 Quaternary Sci 23: 341-350

852 Urey HC, Lowenstam HA, Epstein S, McKinney U (1951) Measurements of paleotemperatures and temperatures of the Upper Cretaceous of England, Denmark and the south-eastern United States. Geol Soc Am Bull 62: 399-416 chironomid $\delta^{13} \mathrm{C}$ as a proxy for past methanogenic contribution to benthic food webs in lakes? J Paleolimnol 43: 235-245

858 van Bennekom AJ, van der Gaast SJ (1976) Possible clay structures in frustules of living 859 diatoms. Geochim Cosmochim Acta 40: 1-6 
860 Varela DE, Pride CJ, Brzezinski MA (2004) Biological fractionation of silicon isotopes in

861 Southern Ocean surface waters. Glob Biogeochem Cy doi:10.1029/2003GB002140

862 Verbruggen F, Heiri O, Reichart G-J and Lotter AF (2010) Chironomid $\delta^{18} \mathrm{O}$ as a proxy for

863 past lake water $\delta^{18} \mathrm{O}$ : a Lateglacial record from Rotsee (Switzerland). Quaternary Sci Rev 29:

$864 \quad 2271-2279$

865 Wang YV, O'Brian DM, Jenson J, Francis D, Wooller MJ (2009) The influence of diet and 866 water on the stable oxygen and hydrogen isotope composition of Chironomidae (Diptera)

867 with paleoecological implications. Oecologia 160: 225-233

868 Wooller MJ, Francis D, Fogel ML, Miller GH, Walker IR, Wolfe AP (2004) Quantitative 869 paleotemperature estimates from $\delta^{18} \mathrm{O}$ of chironomid head capsules preserved in arctic lake 870 sediments. J Paleolimnol 31: 267-274

871 Wooller MJ, Wang Y, Axford Y (2007) A multiple stable isotope record of Late Quaternary 872 limnological changes and chironomid paleoecology from northeastern Iceland. J Paleolimnol 873 DOI 10.1007/s10933-007-9144-8

874 Wooller M, Wang Y, Axford Y (2008) A multiple stable isotope record of Late Quaternary 875 limnological changes and chironomid paleoecology from northeastern Iceland. J

876 Paleolimnology 40: 63-77

877 Zhang Z, Sachs JP (2007) Hydrogen isotope fractionation in freshwater algae: I. Variations 878 among lipids and species. Org Geochem 38: 582-608

879 Zhang Z, Sachs JP, Marchetti A (2009) Hydrogen isotope fractionation in freshwater and 880 marine algae: II. Temperature and nitrogen-limited-growth-rate effects. Org Geochem 40: $881 \quad 428-439$ 


\section{Figures}

884

Figure 1. Stratigraphic profiles of proxies highlighted in the text, plotted on a radiocarboncalibrated age scale: $\delta^{18} \mathrm{O}_{\text {modelled }}$ profile with associated errors linked to mass-balancing isotope measurements from Lake Baikal (see text for details); four stacked records of relative abundance of haematite- stained grains $(\% \mathrm{HSG})$ in North Atlantic sediments indicative of ice-rafted debris events; and $\delta^{18} \mathrm{O}$ from NGRIP ice core. IRD numbers are according to those given in Bond et al. (2001). YD (Younger Dryas) and IACP (intra-Allerød cold period) are also given. Redrawn using data from Mackay et al. (2011).

Figure 2. 25,000-year multi-isotope records from the sediments of crater Lake Challa on the eastern flank of Mt. Kilimanjaro. The combined data suggest three major phases in the history of the lake's carbon cycle in particular the demand exerted by lake productivity regulated by nutrient availability and changes in carbon supplied from the catchment forced by climate as indicated hydrological interpretation of $\delta^{18} \mathrm{O}_{\text {diatom. }}$ Oxygen-isotope ratios $\left(\delta^{18} \mathrm{O}\right)$ in diatom silica are plotted against a reversed axis, the $\delta^{13} \mathrm{C}_{\text {diatom }}$ are a 10 -sample running mean. Also plotted is the difference between $\delta^{13} \mathrm{C}_{\text {diatom }}$ and $\delta^{13} \mathrm{C}_{\text {bulk }}$, the Pearson correlation coefficient (R) between $\delta^{13} \mathrm{C}_{\text {diatom }}$ and $\delta^{13} \mathrm{C}_{\text {bulk }}$ are based on 3000 -yr moving windows of the respective data series. Redrawn using data from Barker et al. (in press).

Figure 3. Comparison of $\delta^{13} \mathrm{C}_{n-\mathrm{C} 23}, \delta^{13} \mathrm{C}_{\mathrm{TOC}}$ and $\delta^{13} \mathrm{C}_{\mathrm{TIC}}$ from Lake Koucha, Tibetan Plateau. The offset between $\delta^{13} \mathrm{C}_{n-\mathrm{C} 23}$ and $\delta^{13} \mathrm{C}_{\text {TOC }}$ : higher values indicate a lower contribution to the organic carbon pool from aquatic macrophytes. The offset between $\delta^{13} \mathrm{C}_{n-\mathrm{C} 23}$ and $\delta^{13} \mathrm{C}_{\mathrm{TIC}}$ : high values are representative of carbon-limited conditions in the lake. Grey horizontal bars signify cooling episodes documented on the Tibetan Plateau. Redrawn using data from Aichner et al. (2010a) and Mischke et al. (2008).

Figure 4. Lake Qinghai $\delta \mathrm{D}_{\text {wax }}$ and $\delta^{18} \mathrm{O}_{\text {carb. }}$. Error bars are indicated on the $\delta \mathrm{D}_{\text {wax }}$ record. It was established the $\delta \mathrm{D}$ of fatty acid $\mathrm{C}_{28}\left(\mathrm{C}_{28} \delta \mathrm{D}\right)$ as an indicator of precipitation $\delta \mathrm{D}$ and used the $\delta^{18} \mathrm{O}$ of lake carbonate $\left(\delta^{18} \mathrm{O}_{\text {carb }}\right)$ as a proxy for regional water balance. The comparison highlights coherent trends between the two proxies, although the $\mathrm{C}_{28} \delta \mathrm{D}$ lags the $\delta^{18} \mathrm{O}_{\text {carb }}$ record, which might reflect the time taken for the integration of terrestrial leaf waxes from the catchment into the sediment record compared to autochthonous deposition of carbonates. Redrawn using data from Liu et al. (2008).

Figure 5. Multiple isotope data from chironomid head capsules from a lake in northeastern Iceland. (a) $\delta^{13} \mathrm{C}$ and (b) $\delta^{15} \mathrm{~N}$ of chironomid head capsules plotted alongside the $\delta^{15} \mathrm{~N}$ and $\delta^{13} \mathrm{C}$ of the sediments; and (c) $\delta^{18} \mathrm{O}$ of mixed insect remains, chironomid head capsules and chironomid adult remains. Large magnitude changes in $\delta^{18} \mathrm{O}$ occurred during the Holocene at the site. Downcore shifts in $\delta^{18} \mathrm{O}$ of chironomids do not correlate with measurements of the $\delta^{13} \mathrm{C}$ and $\delta^{15} \mathrm{~N}$ of chironomid head capsules, implying that the $\delta^{18} \mathrm{O}$ changes were not primarily driven by changes in chironomid diet during the Holocene but more likely changes in the seasonality of precipitation, in the patterns of air masses supplying precipitation to Iceland and in the dominant mode of the North Atlantic Oscillation. Redrawn using data from Wooller et al. (2007). 
Figure 1

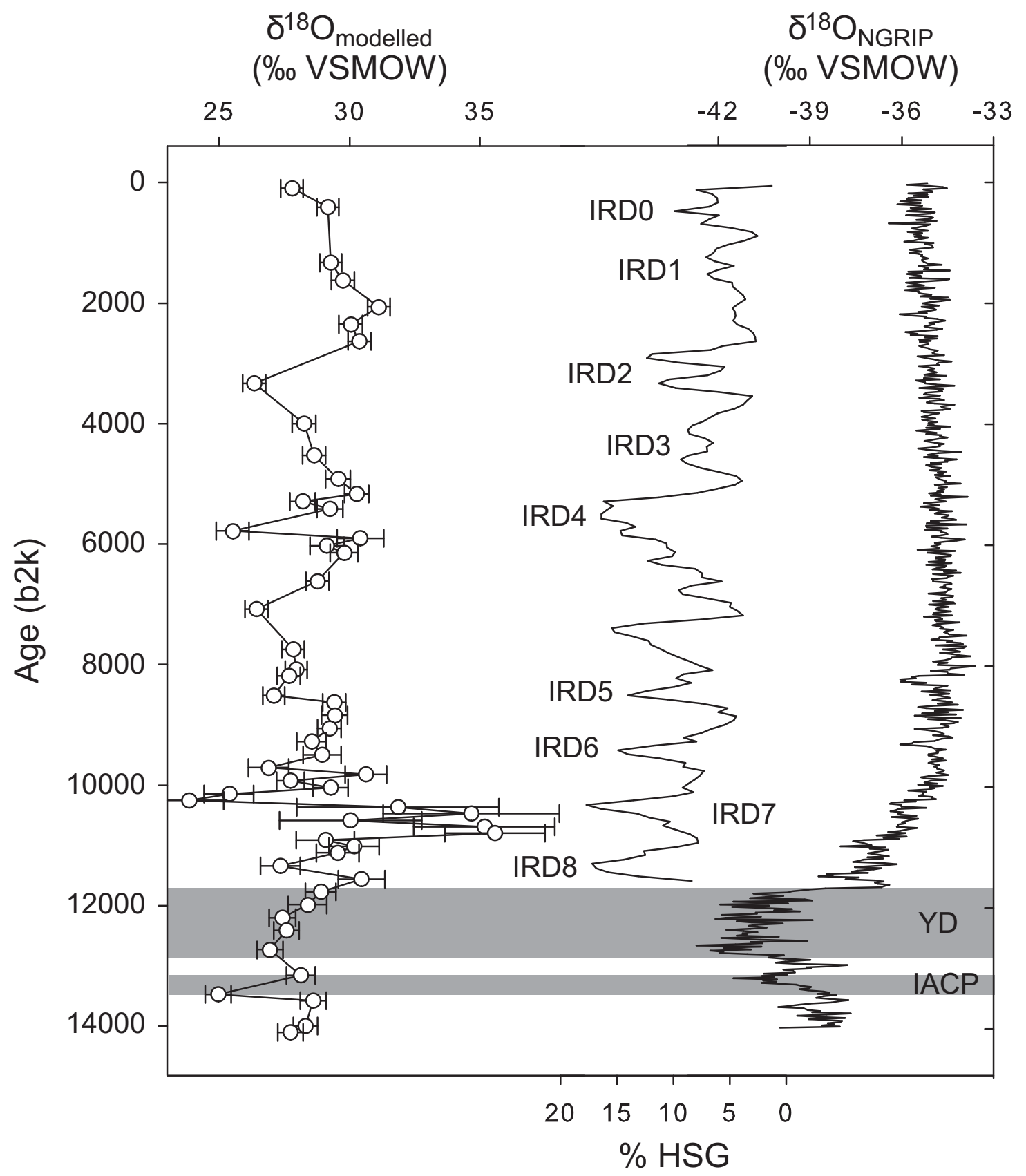


Figure 2




Figure 3

$\delta^{13} \mathrm{C}_{\text {TOC }}$ (\%o VPDB)

-28- $26-24-22-20-18$

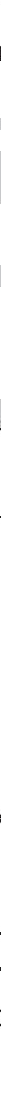

Decreasing contribution of macrophytes to TOC

$$
\delta^{13} C_{n-C 23}-\delta^{13} C_{\mathrm{TI}}
$$

24- $22-20-18-16-$ 
Figure 4

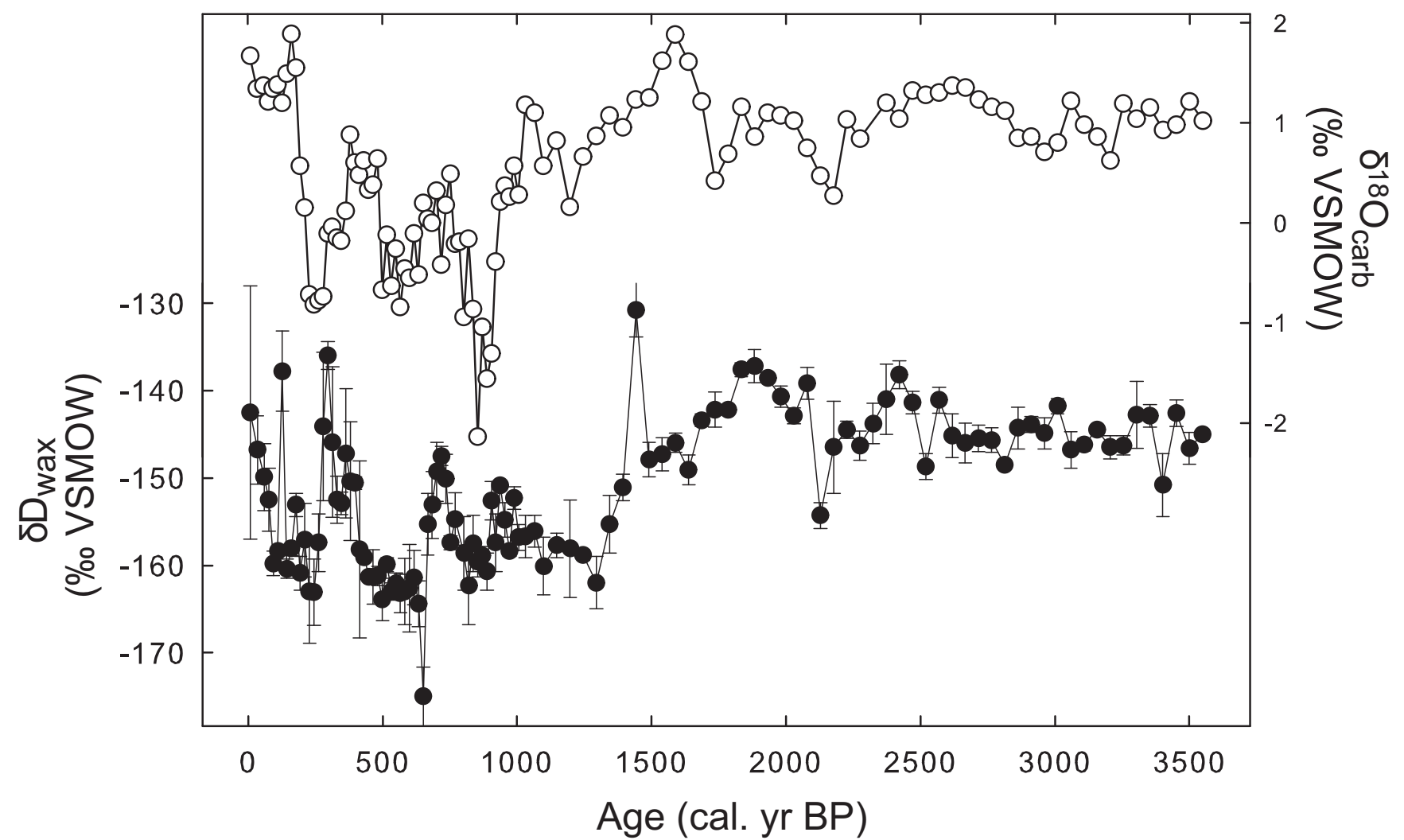


Figure 5
- Chironomid head capsules

列

O Bulk sediment
4

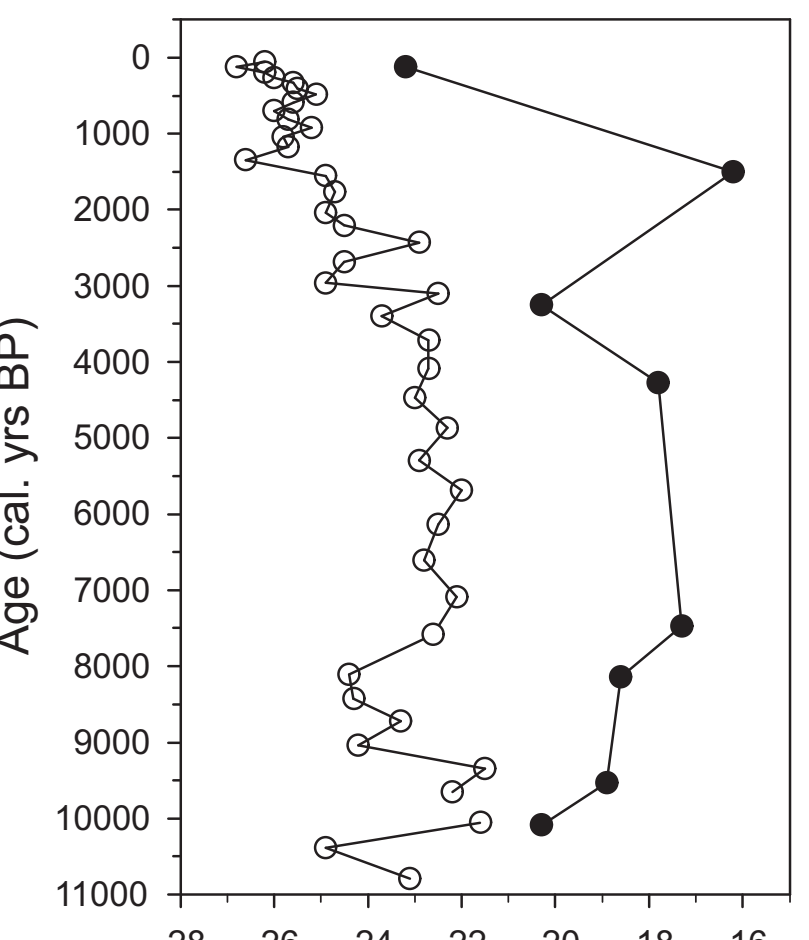

O Bulk sediment

- Chironomid head capsules



- Chironomid head capsules

O Mixed insect chitin

$\nabla$ Chironomid adults

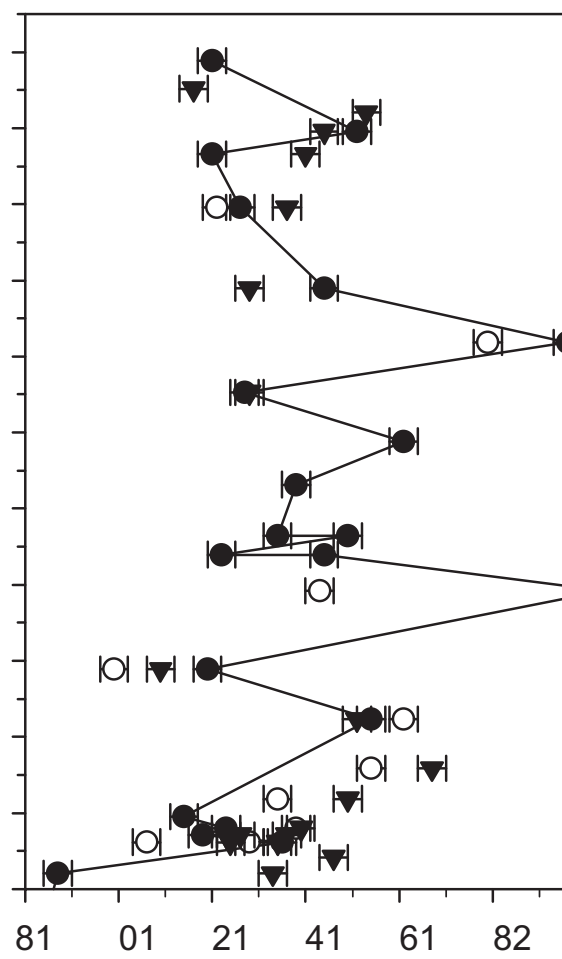

$\delta^{18} \mathrm{O}(\% \mathrm{VSMOW})$ 